\title{
Modern Political Geography
}




\section{Modern Political Geography}

\section{Richard Muir}

Cambridgeshire College of A rts and Technology

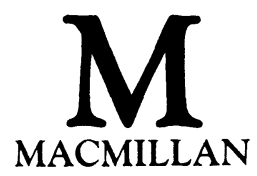


(C) Richard Muir 1975, 1981

All rights reserved. No reproduction, copy or transmission of this publication may be made without written permission.

No paragraph of this publication may be reproduced, copied or transmitted save with written permission or in accordance with the provisions of the Copyright Act 1956 (as amended), or under the terms of any licence permitting limited copying issued by the Copyright Licensing Agency, 33-4 Alfred Place, London WC1E 7DP.

Any person who does any unauthorised act in relation to this publication may be liable to criminal prosecution and civil claims for damages.

First edition 1975

Reprinted 1979

Second edition 1981

Reprinted 1983, 1984, 1987, 1989

Published by

MACMILLAN EDUCATION LTD

Houndmills, Basingstoke, Hampshire RG21 2XS

and London

Companies and representatives

throughout the world

ISBN 978-0-333-31128-8

ISBN 978-1-349-86076-0 (eBook)

DOI 10.1007/978-1-349-86076-0

\section{To my parents}




\section{Contents}

Preface

Introduction to the Second Edition

vii

ix

Acknowledgements $\quad$ xi

Part 1 Introductory 1

1.1 Definitions and approaches 1

1.2 Past development 4

1.3 Prospects 7

$\begin{array}{lll}\text { Part } 2 \text { Political Regions and Time } & 15\end{array}$

2.1 Territory in different forms $\quad 15$

2.2 Development in Europe 19

2.3 The shape of things to come 22

2.4 Theoretical approaches 24

Part 3 Political Regions and Structure 28

3.1 Sovereign territory and its components 28

3.2 The state capital 30

3.3 Core areas 36

3.4 Effective state area $\quad 40$

3.5 Exclaves 43

3.6 Politico-territorial anomalies 48

3.7 The size, shape and location of the state 51

3.8 The landlocked state and access to the sea 57

3.9 Conclusion 64

Part 4 Political Process, Perception and Decision-making 65

4.1 Political process 65

4.2 Perception and decision-making 68

Part 5 Political Process and the State 79

$\begin{array}{lll}5.1 \text { The state } & 79\end{array}$

5.2 Idea and raison d'être of the state: centripetal and centri-
fugal forces

5.3 Nation, nationalism and nation state $\quad 84$ 
5.4 National independence, landscape change and political problems

5.5 National character

5.6 The multinational state 95

$\begin{array}{llr}5.7 & \text { The federal state } & 106\end{array}$

$\begin{array}{lll}5.8 & \text { The insurgent state } & 110\end{array}$

5.9 Measurement of processes $\quad 112$

$\begin{array}{lll}\text { Part } 6 & \text { Frontiers and Boundaries } & 119\end{array}$

$\begin{array}{lll}6.1 & \text { Frontiers } & 119\end{array}$

6.2 Border and relict frontier landscapes $\quad 123$

6.3 Classification of boundaries 126

6.4 The choice and construction of boundaries 130

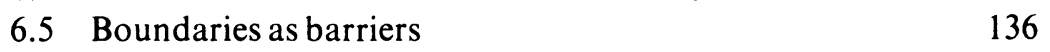

Part 7 Political Geography and the International System 146

$\begin{array}{lll}7.1 & \text { Geography and international relations } & 147\end{array}$

$\begin{array}{lll}7.2 & \text { State power } & 147\end{array}$

$\begin{array}{ll}7.3 & 152 \\ 7.4 & 152\end{array}$

7.4 The geographical significance of international organisations 155

$\begin{array}{ll}7.5 & \text { International trade } \\ 7.6 & 158\end{array}$

$\begin{array}{llr}7.6 & \text { Imperialism } & 162\end{array}$

$\begin{array}{ll}7.7 & \text { The aftermath of imperialism } \\ 7.8 & 165\end{array}$

$\begin{array}{lll}7.8 & \text { Conflict between states } & 172\end{array}$

$\begin{array}{lll}7.9 & \text { Boundary disputes } & 176\end{array}$

$\begin{array}{ll}7.10 & \text { Disputes over resource development } \\ 7.11 & 181\end{array}$

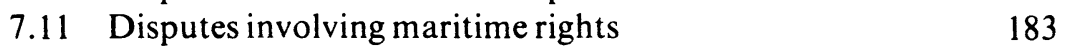

Part 8 Political Regions and Scale 191

8.1 Geopolitical approaches $\quad 192$

$\begin{array}{ll}8.2 \text { International regions } & 198\end{array}$

8.3 Electoral geography 203

8.4 Internal administrative divisions $\quad 211$

$\begin{array}{ll}\text { 8.5 Administrative area reform } & 224\end{array}$

Part 9 Government and the Governed 240

9.1 Government and allocation $\quad 241$

$\begin{array}{lll}9.2 & \text { Decision-making } & 244\end{array}$

9.3 Pressure groups and demand-making 248

$\begin{array}{lll}\text { Appendix } & \text { The systems approaches } & 252\end{array}$

$\begin{array}{ll}\text { References } & 256\end{array}$

$\begin{array}{ll}\text { Index } & 272\end{array}$ 


\section{Preface}

Through lecturing in political geography I have become aware of the need for a textbook that will provide the student with a concise introduction to recent developments in the field and in related fields of study. This is what I have attempted to write. Having so attempted, I anticipate criticism both from those who feel that there is little or no place in political geography for quantitative techniques, models and the like, and from those who consider that I have not progressed far enough in the direction of quantification and abstract theory. I have tried, not consciously to steer a middle course, but to introduce to the reader what are considered to be some valuable innovations which are otherwise accessible only in article form, while at the same time including sufficient descriptive and empirical material to link the more abstract concepts and methodologies firmly to the real world and to allow the work to stand as a textbook in its own right.

Probably the most difficult problem has been that of dividing and subdividing the material, and rather than include numerous short chapters I have used a subdivision based on parts and sections. It appears to me that a useful subdivision of material relating to political regions may be based on a consideration of morphological structure, political process and stage of evolution, provided that the analogies with geomorphology are not stretched too far. Another division can be made on the bases of scale and statehood, separating that material which is internal to the state and that which relates to its external relationships. When these divisions are introduced, it becomes apparent that a great deal of overlap remains, for example in relation to state boundaries, perception and decision-making.

Political geographers are particularly exposed to allegations of subjectivity and political bias; it is inevitable that any piece of writing will be coloured to a greater or lesser extent by the author's opinions and prejudices, and among the more insidious writings are those for which claims of 
objectivity are advanced. I belong to no organised political group or party, and evidence may be found here firstly of my belief in the fundamental equality of men and women of all races and classes, and secondly of my doubts that the sovereign state provides the most suitable framework for satisfying the individual and aggregate needs of men. It may prove difficult to uncover here evidence of partisanship which cannot be reconciled with one or other of these stated biases.

My interest in the interactions between politics and geography developed during my first year at Aberdeen University, when I attended a course of lectures on international relations given by Dr Joseph Frankel, now Professor of Politics at Southampton University. I subsequently joined a special option course in political geography presented by Professor Roy E. H. Mellor, who later supervised my postgraduate research. I was fascinated by his expert descriptions of political-geographical phenomena in Central Europe, and have been grateful for his advice on several occasions since, though I doubt that he would wish to be associated with all the ideas and points of view included here. To Professor Frankel and Professor Mellor, my thanks.

I would also like to thank my geography teacher, Miss L. Davison; that I ever passed my 'A' level is a tribute as much to her patience as to her teaching ability. In the preparation of this book I have been indebted to a number of overworked colleagues: Bronwen Morgan, who drew some of the maps; Russell Gent and Bernard Fingleton, who gave advice on quantitative methods; and Patrick Armstrong, for help in deciphering some systems.

R. M. 


\section{Introduction to the Second Edition}

When I was completing the text of Modern Political Geography in 1974, the course of the future development of the political branch of geography was by no means determined and the discipline was at something of a crossroads. I felt strongly then (as I still do) that if the subject were to reestablish its position within the social sciences, the emphasis of research should be directed towards the detailed study of behavioural processes of a political nature which impact upon the environment. With this bias and the inclusion of certain internationalist value judgements, the book was in some respects radical, and I must admit to fears that it might be savaged by the adherents of an older school. This, to the best of my knowledge, did not occur, and indeed, when compared with some of the subsequent writings by geographers of a radical Marxist persuasion, it seems positively staid.

I imagined that Modern Political Geography would be effective as an advanced text in the subject, and it may be symptomatic of the recent progress made that what I initially used as a third-year text, I now use to support my second-year lecture course. In writing the original edition, I attempted to make the fullest use of contemporary research and, particularly, to introduce relevant material from the related discipline of political science. Even so, I was the only political geography lecturer in East Anglia, and worked very much in isolation. It was therefore a revelation to meet, at the Newcastle 1977 conference of the Institute of British Geographers, with a number of young(ish) fellow workers and to discover that we had quite independently reached the same conclusions concerning the best perspectives to apply to political geographical material. Repeated cycles of academic spending cuts have prevented the establishment of many more 
lectureships within the discipline, but, while claiming no credit for the changes in outlook, I am certain that geographers at large are much more prepared to recognise the significance of political factors than was the case five years ago. In the United Kingdom the discipline also supports a strong core of gifted researchers of my own generation, including not least Neville Douglas, Alan Burnett, Mark Wise, Ronan Paddison and my temporary replacement in Cambridge, Graham Smith.

I feel (without I hope vain bias) that Modern Political Geography has served a useful role. While not displeased with the book, like any author I would like to make a complete rewrite of my work. However, I think that it is essential that the cost factor should be considered. Through no fault of the publishers of textbooks, prices have escalated during recent years and the poor student has borne the burden. I have therefore avoided the sort of radical rewrite which would defeat the object of the exercise by pricing the text beyond the student pocket. I have felt the need to delete very little of the original material and have concentrated on the task of updating the examples, and the most marked additions occur in the respect of the sections on the Law of the Sea.

One serious omission has now been rectified with the addition of a final chapter on Government and the Governed. Had I been more far-sighted in 1974 , I would have recognised the impact that studies of the allocation and demand-making process would have on human geography. Much of the best work in this field has been produced by urban, social and radical geographers and by political scientists, but I offer the material on government allocations, decision-making, demand-making and pressure-group activity as belonging to the mainstream of political geographical interest. With these additions and revisions, plus a more attractive binding, I hope that Modern Political Geography will be of help to the students of the 1980s. 


\section{Acknowledgements}

The author and publisher express thanks for permission granted to reproduce the following diagrams.

Figure 4.3 (a): originally published as Figure 3.9 (b) in Brian P. FitzGerald, Developments in Geographical Method, Oxford University Press (1974); reproduced by permission of The Delegates of the Oxford University Press.

Figure 5.2 (c): originally published in an article by Stanko Zuljic in Geografiski Glasnik, no. 32, Zagreb (1971), subsequently adapted by Jean Hannford of the Department of Geography, University of Texas at Austin and published in Gary M. Bertsch, The revival of nationalism Problems of Communism, issue 22, no. 6, (1973), 22; reproduced by permission of the University of Texas.

Figure 6.3: originally published as Figure 60 in August Lösch, The Economics of Location, Yale University Press (1954); reproduced by permission of Gustav Fischer Verlag, publishers of the original German edition.

Figure 7.1: originally published in Richard L. Merritt, Systems and the disintegration of empires, General Systems, VIII (1963), subsequently republished as Figures 20.1, 20.2, 20.3 in R. K. Kasperson and J. V. Minghi (eds), The Structure of Political Geography, Aldine (1969), University of London Press (1973); reproduced by permission of the Aldine Publishing Company.

Figure 7.6: reproduced by permission of the Embassy of the Republic of Iceland, London.

Figure 8.10: prepared for a seminar held in July 1964 and published in Derek Senior (ed.), The Regional City, Longman (1966), p. 19; reproduced by permission of Mr. Senior and Messrs. Longman. 